\title{
Monitoring the Vegetation and Water Content of Al- Hammar Marsh Using Remote Sensing Techniques
}

Israa J. Muhsin*

\author{
Fouad K. Mashe*
}

Received 3, January, 2011

Accepted 20, May, 2011
Rafid J. Tawfeeq*

\begin{abstract}
:
The object of the presented study was to monitor the changes that had happened in the main features (water, vegetation, and soil) of Al-Hammar Marsh region. To fulfill this goal, different satellite images had been used in different times, MSS 1973, TM 1990, ETM+ 2000, 2002, and MODIS 2009, 2010. A new technique of the unsupervised classification called (Color Extracting Technique) was used to classify the satellite images. MATLAP programming used the technique and separated Al-Hammar Marsh from other water features (rivers, irrigated lands, etc.) when calculated the changes in the water content of the study region. ArcGIS 9.3 (arcMAP, arcToolbox) were used to achieve this work and calculate area of each class.
\end{abstract}

Key words: AL-Hammar marsh, hydrology, color extraction technique.

\section{Introduction:}

The Mesopotamian Marshlands were one of the world's greatest wetlands and the largest such ecosystem in the Southwest Asia. This wetlands ecosystem has been fundamentally changed as a result of upstream dam's construction starting in the late 1950s, and the extensive deliberately draining and drying activities that started in the mid 1980s. In the end of the 20th Century, the Mesopotamian Marshlands was almost vanished. Disappearance of such globally important ecosystem had significant impacts on the environmental equilibrium and the biodiversity on global scale [1].

The problem that raised as the whole marshlands recreation management is concerned was the lack of regular, efficient, precise and cost effective data collection program that supply the information to the decision makers. The project of the recreation of AlHammar marsh imply many changing processes and varied parameters; waters start flowing to the previously drained marshes, extent of these reflooded waters are continuously changing, development of fauna and flora species are closely related to the water depth and its area coverage, many human settlements are re-build again. In general, the marshlands are in accelerating high rate of changing state. These dramatic changes imply land, water and vegetation cover types. Vegetation cover types are expected to undergo significant changes in its types and distribution before and after the restoration stages. Detailed analysis of these vegetation changes will be specifically considered. To properly manage such dynamically active processes, a sustainable remote sensing data collection program is required. To select the adequate and most cost effective imaging system, it is required to determine its spatial, spectral and temporal aspects that capable of

* Baghdad University, College of science, Remote Sensing Unit 
delineating the different marsh cover types and choosing the proper time for image acquisition that corresponds to the phonological stage of the each vegetation cover class. These elements are the main tasks to be tackled in the present research, this research ia attempt to study the important change have been happened on the ALHammar marsh since 1973 until 2010. These changes include the contain of water and marsh vegetation and marsh land), classification technique (supervised and unsupervised) have been used to achieve this study.

\section{Materials and methods:}

The AL-Hammar Marsh is a large complex of wetlands in Iraq that are part of the Tigris-Euphrates river system it is lies in $(645956.65 \mathrm{E}-$ 767003.37E) latitude and (3429652.25N-3365990.54N)

longitude, see figure (1), its surrounding marshes and neighboring marshes and areas of temporary inundation comprise some $3,500 \mathrm{~km}^{2}$ of almost contiguous wetland habitat. Its consider to be the largest lake in the lower Euphrates, approximately 120 $\mathrm{km}$ long by up to $25 \mathrm{~km}$ wide. It is bordered in the north by the River Euphrates, in the west by the Southern Desert and in the east by the Shatt Al Arab. Generally The lake is, shallow with a maximum depth of about $1.8 \mathrm{~m}$ at low-water levels in early winter and about $3.0 \mathrm{~m}$ at high-water levels in late spring. Large parts of the littoral zone dry out during periods of low water and banks and islands appear in many places. [1]

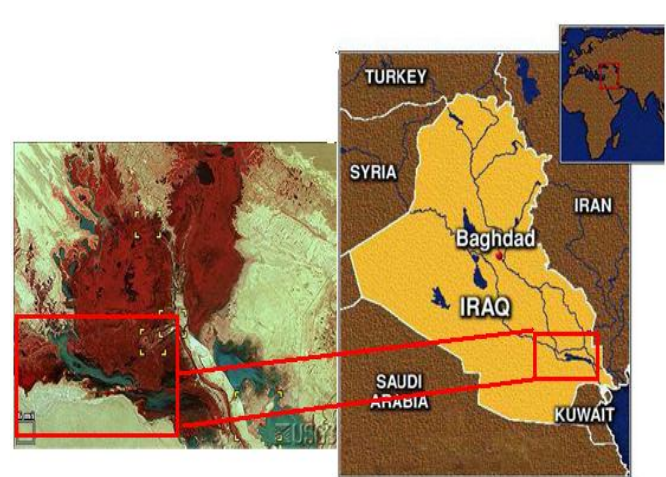

Fig.1 : Represent the studied area. [1]

\section{The goal of the president work}

The goal of this project is to support the sustainable management and restoration of Al- Hammar marsh, with the following immediate objectives:

$\checkmark$ To monitor and assess baseline characteristics of the marshland conditions, to provide objective and up-to-date information, and to disseminate tools needed for assessment and management

$\checkmark$ To build capacity of Iraqi decision makers and community representatives on aspects of marshland management, including: policy and institutional aspects, technical subjects, and analytical tools.

$\checkmark$ Monitoring the important change include (water, vegetation, soil) and this led to find the most important tools to develop this marsh.

\section{Hydrology}

Most of the Iraq water resources originate from outside Iraq where 88 percent of the natural runoff of the Euphrates comes from Turkey, 9 percent from Syria and the remainder from Iraq. As for the Tigris, 56 percent of its natural runoff comes from Turkey, 12 percent from Iran (especially for the two tributaries, lower Zab and Diyala rivers), while source of the remaining water is from within Iraq [2]. The combined 
watersheds of the two rivers cover $950,876 \mathrm{~km}^{2}$. All of the water contained in the watershed must pass through these marshes on the way to the Gulf. The marshes are nourished by periodic flood pulses of the rivers, and are highly sensitive to water quality conditions altered upstream. Most of the water that flows through the basin originates as snowfall in the Anatolian highlands of Turkey, and the Zagros mountain range of Iraq and Iran. [3].

The hydrology of the Al-Hammar marsh is not clear: its main source of water re-charge appears to be the Euphrates, but it may also receive a very substantial amount of water from the Tigris via the Central Marshes, and there is presumably also some recharge from groundwater. The Euphrates flows through the marshes and joins the Tigris at Qarmat Ali, where the combined flow becomes the Shatt Al- Arab. [4]

\section{Methodology:}

The main objectives of the present work consist of three stage; first, define and locale the main cover types of the Marshes, second, track and detect the changes encountered in these cover types during the last three decades time episodes (1973-2010), and finally, determine the cover area of each object (water, vegetation, and soil).

To fulfill this study, LANDSAT (MSS 1973, TM 1990, ETM+ 2000, 2002, and MODIS 2009, 2010), Adaptive unsupervised technique has been adopted to achieve the classification process. this technique depend on Automatic color extraction, where the main lines of this technique can be summarized as transformation the study, transformed the image data from RGB to HSV-color spaces, Where: $R, G, B$ are the Red, Green, Blue, and $H, S, V$ are the Hue, Saturation, and Value respectively.
By using the transformation equations [5]:

$$
\begin{aligned}
& V=R+G+B \\
& H=\frac{G-B}{V-3 B} \\
& S=\frac{V-3 B}{V}
\end{aligned}
$$

The

boundary conditions for extracting the green color or for vegetation extracting

$\left(V_{-}\right.$extracted $)$can be shown in figure (3), such that all the green color delineated in a rectangular, then put these boundaries in a mathematics form, similarly for extracting the blue color. Thus ( $V_{-}$extracted $)[6]$ are:

$(0.195 \leq H \leq 0.46)$ and $(0.2 \leq S \leq 1)$ and $(0.2 \leq V \leq 1)(4)$

In addition, the boundary conditions for extracting the blue color or for water extracting ( $W_{-}$extracted $)$ are:

$(0.557 \leq H \leq 0.71)$ and $(S \geq 0.3)$ or $(V \leq 0.18)(5)$

For soil extracting $\left(S_{-}\right.$extracted $)$, the work supposed that the remaining main feature was soil, and thus, its color boundary conditions are:

$I(5,4,3) \neq\left(V_{-}\right.$extracted or $W_{-}$extracted $)(6)$

Where $I(5,4,3)$ represents the RGB image with $\mathrm{R}=$ band $5, \mathrm{G}=$ band 4 , and $\mathrm{B}=$ band 3 .

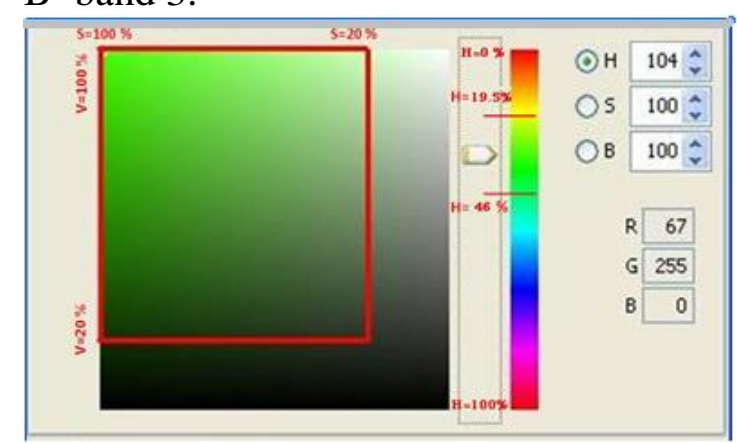

Fig. (2): illustration, Extract of Green Color. 
Notice in figure (2), the value of V,S, and $H$, represent the Hue, Saturation, and Value respectively to Extract of Green Color. The same of manner find Extract of Blue color.

According to the previous color boundary conditions, the images classified and the results can be shown as below figures where the figure (3) represent the landsat image classification(1973,1990, 2000,2002) while the figure (4) represent the result classification of MODIS image (2009,2010).
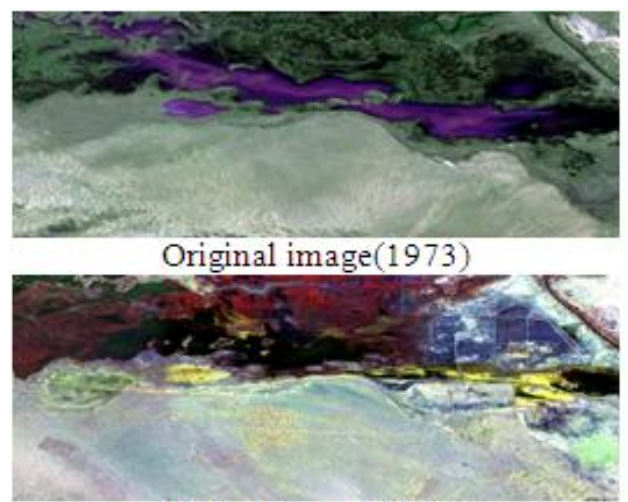

Original image (1990)

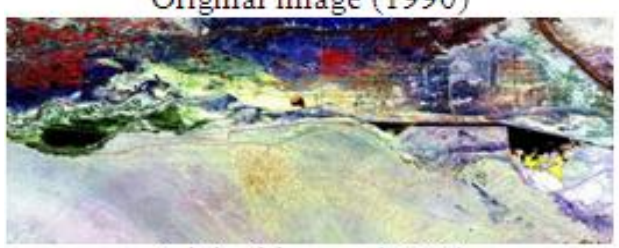

Original image (2000)

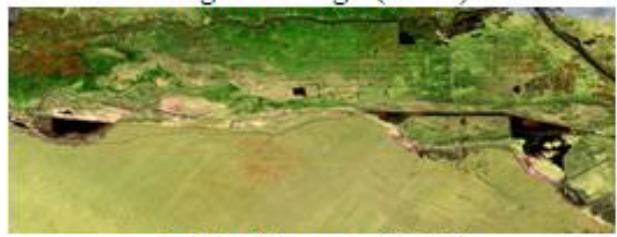

Original image (2002)

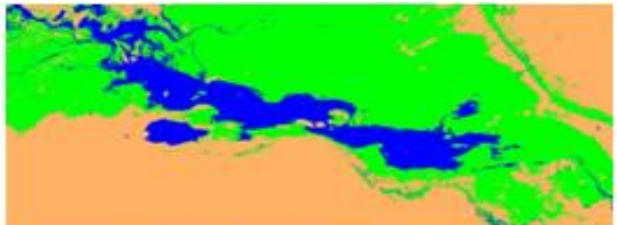

Classified image (1973)

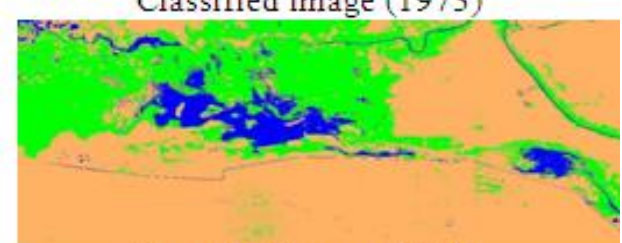

Classified image (1990)

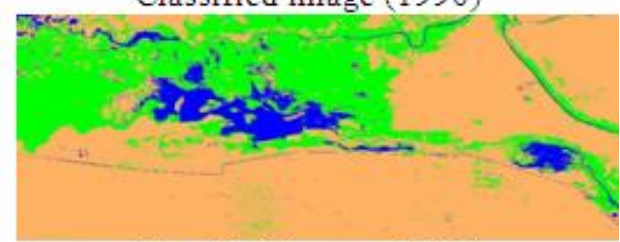

Classified image (2000)

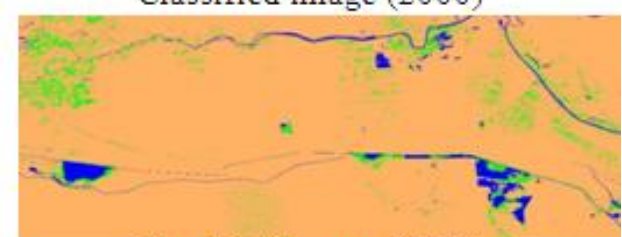

Classified image (2002)

Fig. (3): Represent the results of LANDSAT images classification
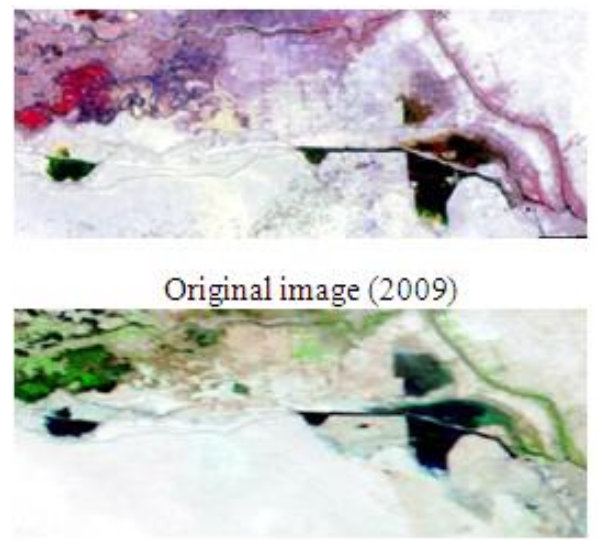

Original image (2010)

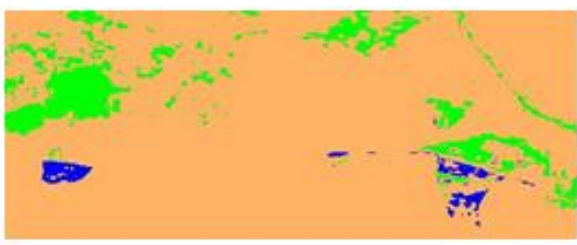

Classified image (2009)

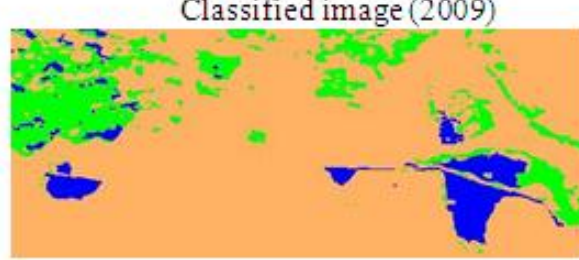

Classified image (2010)

Fig. (4): Represent the results of MODIS images classification 
The area of Al-Hammar marsh objects (water, vegetation, and soil) can be distributed statistically as show in figure (5) while the value of these areas can be noticed in table (2).

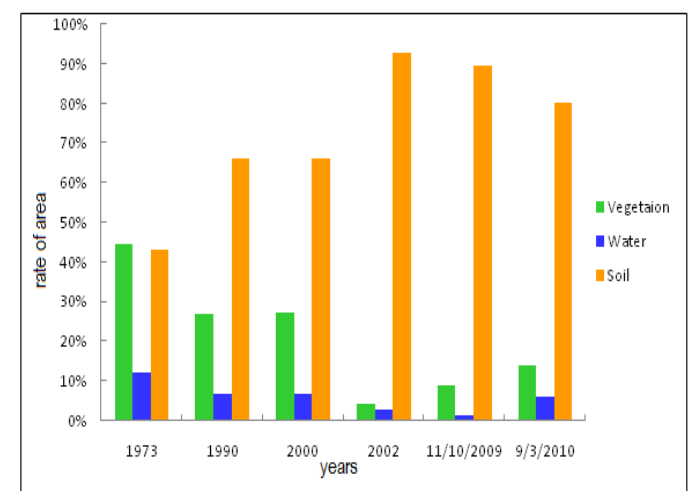

Fig. (5): Represent Al-Hammar marsh objects (vegetation, water, and soil) distribution

Table (1): Show the area distribution of Al-Hammar marsh objects (vegetation, water, and soil)

\begin{tabular}{|c|c|c|c|c|c|c|}
\hline \%ear & 1973 & 1990 & 2000 & 2002 & $\begin{array}{c}11-10- \\
2009\end{array}$ & $\begin{array}{c}9-3- \\
2010\end{array}$ \\
\hline Vegeatation & 44.43 & 27.13 & 27.17 & 4.20 & 9.03 & 13.99 \\
\hline Water & 12.24 & 6.74 & 6.73 & 2.93 & 1.4 & 5.95 \\
\hline Soil & 43.34 & 66.13 & 66.10 & 92.87 & 89.57 & 80.06 \\
\hline
\end{tabular}

\section{Discussion}

Protecting and monitoring of ALHammar marsh objects (vegetation, water, and soil) is major concerns for many local and state agencies. Highresolution satellite remote sensing is an important tool that can potentially be applied to gather information needed for water, vegetation and soil area assessments in the marshes. The assessment has been achieved using adaptive technique of the unsupervised classification called Color Extracting Technique, the classification of this technique depends on the degree of the color of each object accurately, two types of satellites (LANDSAT and MODIS) were used and very good results had been gotten as show in figures (3) and (4). The statistical distribution of the objects can be shown in the figure (5) and table (1). It is clear that the amount of the vegetation area proportion with the amount of the water. The unexpected decreasing in the water amount at 1990 and later has been happened because of the political decisions of the Iraqi leadership, as well as building of many large dams in Turkey play an important role for reducing the water in Iraq marshes especially ALHammar marsh. The amount of the soil in the studied region inverse proportional with the amount of the water as cleared in the above table.

\section{References:}

1.Curtis, J.R and najah, A.H 2006. "Restoring the Erden of Eden an Ecological Assessment of the Marsh Of Iraq".

2.USAID, 2003. "Iraq Marshlands Restoration Program". United State Agency International Development.

3.Curtis, J.R Peter, R., Najah, A. H., Azzam, J. A. and Douglas, J. P., 2005. "The Restoration Potential of the Mesopotamian Marshes of Iraq". Science 25: 1307 - 1311.

4.Birdlife International 2009. "Important Bird Area factsheet: Haur Al Hammar, Iraq".

5. Floyd, F. S., 1987."Remote Sensing Principles and Interpretation", W. H.Freeman and company; New York, 2nd Ed., p. 252.

6.John, A. R., and Xiuping J., 2006. "Remote Sensing Digital Image Analysis", Springer-Verlag Berlin Heidelberg, 4th Ed, p. 295. 
مراقبة النباتات والمحتوى المائي لهور الحمار بأستخدام تقانات الاستشعارعن بعد رافد جميل توفيق*

"جامعة بغداد, كلية العلوم, وحدة الاستشعار عن بعد *

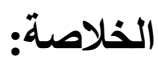
يتضمن هذا البحث دراسة التغيرات الحاصلة على الخصائص الاساسية ( النباتات, الماء رالتربة) لمنطقة هور

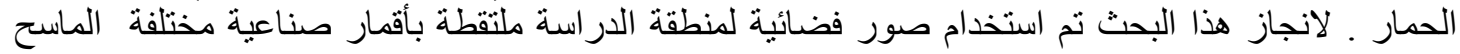

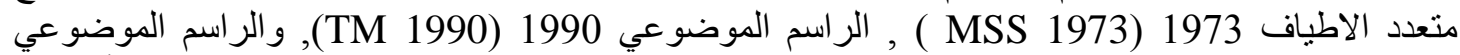

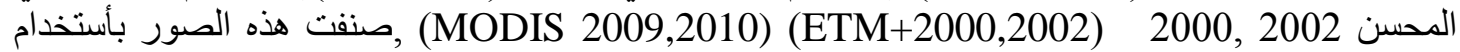
تقانة تصنيف غير مراقب جديدة تعتمد على استقطاع اللون من صور حزمة مركبة, كما تم استخدام الحقيبة

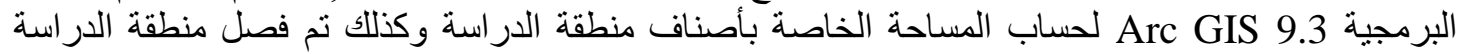
المتمثلة بمنطقة هور الحمار عن بقية الموارد المائية من انهار وروافد و البقاء على خصائص الصورة الصنية الاصلية الصلية لمر اقبة التغير الحاصل في محتو اها المائي والنباتي. لمني. 